Review

\title{
Genomic Features and Clinical Management of Patients with Hereditary Pancreatic Cancer Syndromes and Familial Pancreatic Cancer
}

\author{
Akihiro Ohmoto ${ }^{1, * \mathbb{C}}$, Shinichi Yachida ${ }^{1,2}$ and Chigusa Morizane ${ }^{3}$ \\ 1 Laboratory of Clinical Genomics, National Cancer Center Research Institute, Tokyo 1040045, Japan; \\ syachida@cgi.med.osaka-u.ac.jp \\ 2 Department of Cancer Genome Informatics, Graduate School of Medicine/Faculty of Medicine, Osaka \\ University, Osaka 5650871, Japan \\ 3 Department of Hepatobiliary and Pancreatic Oncology, National Cancer Center Hospital, Tokyo 1040045, \\ Japan; cmorizan@ncc.go.jp \\ * Correspondence: aohmoto@ncc.go.jp; Tel.: +81-(3)3542-2511; Fax: +81-(3)3545-3567
}

Received: 26 December 2018; Accepted: 28 January 2019; Published: 29 January 2019

check for updates

\begin{abstract}
Pancreatic cancer (PC) is one of the most devastating malignancies; it has a 5-year survival rate of only $9 \%$, and novel treatment strategies are urgently needed. While most PC cases occur sporadically, PC associated with hereditary syndromes or familial PC (FPC; defined as an individual having two or more first-degree relatives diagnosed with PC) accounts for about $10 \%$ of cases. Hereditary cancer syndromes associated with increased risk for PC include Peutz-Jeghers syndrome, hereditary pancreatitis, familial atypical multiple mole melanoma, familial adenomatous polyposis, Lynch syndrome and hereditary breast and ovarian cancer syndrome. Next-generation sequencing of FPC patients has uncovered new susceptibility genes such as PALB2 and ATM, which participate in homologous recombination repair, and further investigations are in progress. Previous studies have demonstrated that some sporadic cases that do not fulfil FPC criteria also harbor similar mutations, and so genomic testing based on family history might overlook some susceptibility gene carriers. There are no established screening procedures for high-risk unaffected cases, and it is not clear whether surveillance programs would have clinical benefits. In terms of treatment, poly (ADP-ribose) polymerase inhibitors for $B R C A$-mutated cases or immune checkpoint inhibitors for mismatch repair deficient cases are promising, and clinical trials of these agents are underway.
\end{abstract}

Keywords: hereditary cancer syndrome; Lynch syndrome; familial pancreatic cancer; next-generation sequencing; germline mutation; surveillance; PARP inhibitor; immune checkpoint inhibitor

\section{Introduction}

Pancreatic cancer (PC) is one of the most devasting malignancies worldwide. In spite of advances in early detection, surgical techniques and new systemic treatment, the 5-year survival rate in PC patients is still only about 9\% [1]. According to the Global Cancer Statistics 2018, PC is ranked as the seventh leading cause of cancer-related mortality, accounting for $4.5 \%$ of all malignancy cases [2]. Previous studies have implicated lifestyle-related factors such as smoking, heavy alcohol consumption, obesity and diabetes mellitus in PC onset, and most PC cases develop sporadically [3]. Thus, identifying patients with predisposing genetic factors seems an attractive strategy for improving clinical outcomes. It is estimated that $3 \%$ of PC cases derive from hereditary cancer syndromes, and another $7 \%$ of the cases are classified as familial PC (FPC), which is defined as an individual who has two or more first-degree relatives (FDRs) with PC [4,5]. 
Clinical management for PC probands necessarily raises the problem of surveillance, including counseling, for unaffected relatives. The main purpose of surveillance for high-risk relatives is the detection of precursor lesions or early PC, which is the only point at which a curative approach may be feasible at present. However, standard screening procedures have not been settled, and it is not yet clear whether screening programs offer clinical benefits. As regards treatment, molecular-targeted agents or immune therapies are rapidly being introduced into clinical practice even though their usefulness for PC is not established. However, favorable data has emerged in clinical trials of poly (ADP-ribose) polymerase (PARP) inhibitors for BRCA-mutated cases or anti-PD-1 antibodies for mismatch repair (MMR)-deficient cases. Here, we present an overview of the latest studies on PC associated with hereditary cancer syndromes and FPC, focusing on genomic data, and we describe the current status and future prospects of surveillance programs and therapeutic interventions.

\section{Hereditary Pancreatic Cancer Syndromes}

Several hereditary syndromes are associated with the onset of PC. The 2015 clinical guideline for hereditary gastrointestinal cancer syndromes by the American College of Gastroenterology (ACG) covers Peutz-Jeghers syndrome (PJS), hereditary pancreatitis (HP), familial atypical multiple mole melanoma (FAMMM), familial adenomatous polyposis (FAP), Lynch syndrome (LS) and hereditary breast and ovarian cancer syndrome (HBOC), together with Li-Fraumeni syndrome harboring TP53 mutation or ataxia-telangiectasia harboring ATM mutation [6]. Representative hereditary syndromes with specific germline mutations are summarized in Table 1.

\subsection{Peutz-Jeghers Syndrome (PJS)}

PJS is an autosomal dominant inherited syndrome. Perioral/buccal pigmentation and gastrointestinal multiple hamartomatous polyps are characteristic of PJS, and these symptoms are seen in more than $95 \%$ and $88-100 \%$ of cases, respectively [6]. Pathologically, intraductal papillary mucinous neoplasm (IPMN) as a precursor lesion of pancreatic ductal adenocarcinoma (PDAC) is observed in some patients with PJS [7]. Inactivating mutations of the STK11/LKB1 gene regulating cell growth, proliferation and DNA damage response are causative for PJS [8]. This syndrome increases the incidence of $\mathrm{PC}$, as well as gastrointestinal, lung, breast, uterus and ovarian cancers [9]. A meta-analysis covering 210 PJS cases showed a 15.2-fold increased risk of any cancer, and the risk was especially high for PC (132-fold), as well as esophageal cancer (57-fold), stomach cancer (213-fold) and small intestinal cancer (520-fold) [9]. Hearle et al., reported that 297 of 419 (70.9\%) cases with PJS harbored STK11/LKB1 mutation, and cumulative risks of any cancer and PC were $85 \%$ and $11 \%$, respectively, at 70 years of age [10]. Here, the cumulative risk of any cancer was not significantly different between the cases with STK11/LKB1 mutation and those without the mutation $(p=0.43)$. In an analysis of a series of 240 PJS patients harboring STK11 mutation, cumulative PC risk was $8 \%$ at 60 years of age [11]. These data highlight PJS as one of the highest risk factors for PC onset.

\subsection{Hereditary Pancreatitis (HP)}

Patients with HP suffer from recurrent acute pancreatitis, leading eventually to chronic pancreatitis. Because sporadic chronic pancreatitis usually occurs in elderly people, early onset (age $<25$ years) is a clue for suspecting HP [12]. Activating mutations in PRSS1 encoding the cationic trypsinogen related to trypsin activation, and inactivating mutations in SPINK1 inhibiting trypsin are causative for this syndrome [13]. It is suggested that repeated mechanical damage to acinar cells due to continuous trypsin activation induces PC onset. Pancreatic cancer deriving from HP usually exhibits the pathology of typical PDAC [7]. Lowenfels et al. reported that HP increased PC risk by 53 -fold and the cumulative PC risk reached $40 \%$ at 70 years of age [14]. An analysis of a series of $200 \mathrm{HP}$ patients showed 87-fold increased PC risk, and cumulative PC risk was 53.5\% at 75 years of age [15]. According to a recent study of 217 PRSS1 mutation carriers, R122H and N29I variants were detected in $83.9 \%$ and $11.5 \%$ of the cases, respectively, and cumulative PC risk was $7.2 \%$ at 
70 years of age [16]. The cumulative risk estimated in this study is much lower than those found by Lowenfels et al. and Rebours et al. [14,15], though this might be explained by different patient backgrounds, referral bias or lifestyle changes including smoking. In genomic analysis of a series of 41 Polish children with HP, Oracz et al. detected PRSS1 mutation in $80.5 \%$ of the cases $(34 \% \mathrm{R} 122 \mathrm{H}$ variant; 27\% R122C; 12\% N29I; 7\% E79K) [17]. Rebours et al. also conducted a genomic analysis of a cohort of 200 French HP cases, and detected PRSS1 mutation in 68\% (53\% R122H variant; 8\% N29I) and SPINK1 mutation in 13\% of the cases [18]. A Japanese survey of 271 patients in $100 \mathrm{HP}$ families showed a PRSS1 mutation prevalence of $41.1 \%$ and a SPINK1 mutation prevalence of $35.6 \%$ [19]. The decreased ratio of PRSS1-mutated cases compared with the western cohort might reflect different genomic backgrounds among ethnic groups [17-19]. As with PJS, HP is categorized as one of the highest risk factors for PC.

\subsection{Familial Atypical Multiple Mole Melanoma (FAMMM)}

Patients with FAMMM have multiple (usually > 50) atypical nevi progressing to melanoma [20]. FAMMM leads to increased incidences of $P C$ as well as breast, lung and endometrium cancers [12]. Inactivating mutations in $C D K N 2 A(p 16)$ inducing $G_{1} / G_{2}$ cell cycle arrest are causative for this syndrome [8]. PC deriving from FAMMM is pathologically ordinary [7]. Vasen et al. showed that cumulative PC risk in FAMMM families harboring CDKN2A mutation was $17 \%$ at 75 years of age [21]. Goldstein et al. and De Snoo et al. reported that relative PC risk in families with CDKN2A mutation was 13.1-22 and 46.6, respectively [22,23]. While self-monitoring of nevi is useful in detecting melanoma, surveillance procedures for detecting pancreatic lesions early have not been fully established [24]. Vasen et al. monitored 77 germline $C D K N 2 A$ mutation carriers with magnetic resonance imaging (MRI) or magnetic resonance cholangiopancreatography (MRCP), and detected $7(9.1 \%)$ resectable PC cases, concluding that further studies are warranted [25].

\subsection{Familial Adenomatous Polyposis (FAP)}

FAP is characterized by hundreds of synchronous colorectal adenomas, and these adenomas inevitably progress into malignancies at an average age of 35-40 years [26]. APC regulating cell migration and adhesion and MUTYH participating in base excision repair are causative genes for FAP [8]. Giardiello et al. reported that FAP increased PC risk by 4.5 -fold and cumulative PC risk was $1.7 \%$ at 80 years of age [27]. A pathological review of four PC cases deriving from FAP found that all of them exhibited unusual histology (poorly differentiated neuroendocrine carcinoma, acinar cell carcinoma and pancreatoblastoma) [28]. Among them, gene mutations in the APC/ $\beta$-catenin pathway were detected in pancreatoblastoma, indicating a molecular interaction between FAP and pancreatoblastoma [29].

\subsection{Lynch Syndrome (LS)}

Patients with LS suffer from colorectal cancer at early ages (typically in the mid 40 years, which is about 20 years younger than sporadic cases). LS is also termed hereditary nonpolyposis colorectal cancer, and is genetically characterized by the presence of inactivating mutations in MMR genes (MLH1, MSH2, MSH6 and PMS2) and EPCAM [6]. EPCAM was newly discovered as a causative gene for LS, and $3^{\prime}$ end deletion of this gene causes epigenetic silencing of the MSH2 gene in EPCAM-expressing tissue [30]. The revised Bethesda Guidelines (RBG) for identifying MMR gene mutation carriers categorize PC as one of the LS-associated neoplasms, along with other types of malignancies such as endometrial, small intestinal or ureter/renal pelvic cancers [31]. Pathologically, medullary carcinoma, a rare subtype, is uniquely observed in LS-derived PC [7]. Kastrinos et al. analyzed 6,342 PC probands and relatives from 147 families harboring MMR gene mutations, and found that this syndrome increased PC risk by 8.6 -fold and cumulative PC risk was $3.7 \%$ at 70 years of age [32]. A recent prospective observational study of 3119 MMR-mutation carriers found that relative 
cumulative PC risk was 7.8 (95\% CI: 3.3-12.3) in MLH1 mutation carriers at 75 years of age, although MSH2, MSH6 or PMS2 carriers did not show increased risk [33].

Considering the worldwide clinical investigations of immune checkpoint inhibitors, identifying MMR-mutated cases has become practically more important. Our group selected $20(6.6 \%)$ patients with a personal or family history consistent with RBG from a cohort of 304 Japanese PC patients, and analyzed germline variants of 21 hereditary cancer susceptibility genes [34]. We detected PMS2 mutation in only one case $(0.3 \%$ of all 304 cases). Hu et al. exhaustively conducted immunohistochemistry (IHC), microsatellite instability (MSI) testing and germline DNA sequencing in a series of 833 PC patients, and identified $7(0.8 \%)$ MMR mutation carriers, including 5 cases meeting RBG criteria [35]. Because of the lower lifetime PC risk (1-6\%) compared with colorectal cancer $(10-82 \%)$ or endometrial cancer (15-60\%), clinical evidence that universal tumor screening would be effective in patients with LS, as recommended for colorectal or endometrial cancers, is scarce for PC [36]. In order to find favorable candidates for immunotherapy, $\mathrm{Hu}$ et al. proposed a practical algorithm for efficiently extracting MMR-deficient PC cases, in which IHC or MSI testing is initially assigned to resected cases, and next-generation sequencing to metastatic/locally advanced cases [35].

\subsection{Hereditary Breast and Ovarian Cancer Syndrome (HBOC)}

HBOC is a syndrome characterized by breast and ovarian cancers occurring before the age of 50 , and accounts for $5-10 \%$ of breast cancers and $10-15 \%$ of ovarian cancers [37,38]. HBOC is genetically caused by inactivating mutations in $B R C A 1 / B R C A 2$, which are involved in the homologous recombination repair (HRR) pathway. While $B R C A 2$ mutation is widely accepted as a PC risk factor, the data for $B R C A 1$ mutation are conflicting [39]. Iqbal et al. prospectively identified $8 \mathrm{PC}$ cases from $3942 B R C A 1$ and $1147 B R C A 2$ mutation carriers, and reported that the relative PC risk compared with the general population was 2.6 (95\% CI: 1.0-5.3) in BRCA1 carriers and 2.1 (95\% CI: 0.4-7.0) in BRCA2 carriers [40]. According to a study of $613 B R C A 1$ and $459 B R C A 2$ mutation carriers, relative PC risk for $B R C A 2$ mutation carriers was 21.7 (95\% CI: 13.1-34.0), whereas BRCA1 mutation did not significantly increase the risk [41]. As Klein noted, the above studies did not establish whether a past history of breast or ovarian cancer is essential to the diagnosis of HBOC. Therefore, it is not clear whether PC risk is similar between $B R C A 1 / 2$ carriers fulfilling the criteria of $\mathrm{HBOC}$ and those not meeting the criteria [3].

Table 1. Clinical and germline genomic features in hereditary syndromes.

\begin{tabular}{|c|c|c|c|c|}
\hline Syndrome & Clinical Features & Causative Gene & Relative PC Risk & Cumulative PC Risk \\
\hline PJS & $\begin{array}{l}\text { - Perioral/buccal } \\
\text { pigmentation } \\
\text { - Gastrointestinal } \\
\text { hamartomatous polyp }\end{array}$ & STK11/LKB1 & 132-fold [9] & $\begin{array}{l}11 \% \text { (70 years) }[10] \\
8 \% \text { (60 years) [11] }\end{array}$ \\
\hline $\mathrm{HP}$ & Recurrent acute pancreatitis & PRSS1, SPINK1 & $\begin{array}{l}\text { 53-fold [14] } \\
87 \text {-fold [15] }\end{array}$ & $\begin{array}{c}40 \% \text { (70 years) }[14] \\
53.5 \% \text { ( } 75 \text { years) }[15] \\
7.2 \% \text { (70 years) }[16]\end{array}$ \\
\hline FAMMM & Multiple atypical nevi & CDKN2A & $\begin{array}{c}\text { 13.1, 22-fold [22] } \\
\text { 46.6-fold [23] }\end{array}$ & $17 \%$ (75 years) $[21]$ \\
\hline FAP & $\begin{array}{l}\text { Hundreds of synchronous } \\
\text { colorectal adenomas }\end{array}$ & APC, MUTYH & 4.5 -fold [26] & $1.7 \%$ (80 years) $[26]$ \\
\hline LS & $\begin{array}{l}\text { Nonpolyposis colorectal } \\
\text { cancer at early ages }\end{array}$ & $\begin{array}{l}\text { MLH1, MSH2, } \\
\text { MSH6, PMS2 }\end{array}$ & 8.6-fold [31] & $3.7 \%$ (70 years) $[31]$ \\
\hline HBOC & $\begin{array}{l}\text { Breast and ovarian cancers } \\
\text { occurring at early ages }\end{array}$ & $B R C A 1, B R C A 2$ & $\begin{array}{c}\text { BRCA1:2.6-fold [39] * } \\
\text { BRCA2:2.1-fold [39] *, } \\
\text { 21.7-fold [40] * }\end{array}$ & NA \\
\hline
\end{tabular}

PC, pancreatic cancer; PJS, Peutz-Jeghers syndrome; HP, hereditary pancreatitis; FAMMM, familial atypical multiple mole melanoma; FAP, familial adenomatous polyposis; LS, Lynch syndrome; HBOC, hereditary breast and ovarian cancer syndrome; NA, not available. * Past history of breast or ovarian cancer is unavailable. 


\section{Familial Pancreatic Cancer (FPC) and Susceptibility Genes}

As mentioned above, FPC refers to individuals having two or more FDRs with PC, and patients associated with hereditary syndromes are excluded from this category [5]. From the viewpoint of clinicopathological features, Singhi et al. compared 519 FPC and 651 sporadic PC, and reported that there was no significant difference in histological subtype, patient age, tumor size, tumor location, peripheral invasion, angiolymphatic invasion, lymph node metastasis or pathological stage [42]. According to a prospective cohort study of 5,179 individuals from 838 families, the relative PC risk was 4.5 (95\% CI: 0.5-16.3) in 1,253 cases with one affected FDR, 6.4 (95\% CI: 1.8-16.4) in 634 cases with two affected FDRs, and 32.0 (95\% CI: 10.4-74.7) in 106 cases with three or more affected FDRs [43]. A meta-analysis including seven case-control and two cohort studies demonstrated that an individual with an affected relative, irrespective of the degree of relationship, had an increased PC risk of 1.8 (95\% CI: 1.5-2.1) [44]. A pooled analysis from the Pancreatic Cancer Cohort Consortium also showed that an individual with a family history of PC in an FDR had an increased PC risk of 1.8 (95\% CI: 1.2-2.6) [45]. These reports confirm that the existence of an affected FDR is a significant PC risk, especially where there is a strong family history.

Next-generation sequencing has contributed to the discovery of novel FPC susceptibility genes such as PALB2 or ATM. Initially, Murphy et al. identified germline BRCA2 mutation in 5 of $29(17.2 \%)$ FPC patients, including 3 cases harboring 6174delT frameshift variant [46]. Hahn et al. also identified a germline $B R C A 2$ frameshift variant in 3 of a cohort of $26(11.5 \%)$ FPC patients [47]. It is known that $B R C A 2$ mutation prevalence differs among ethnic groups, and is especially high in Ashkenazi Jews. Germline mutation analysis of 5,318 Jewish subjects detected BRCA2 6174delT variant in $1.2 \%$, as well as BRCA1 185delAG or 5382insC variant in 1.2\% [48]. In contrast to BRCA2, the involvement of $B R C A 1$ in FPC is controversial. Indeed, germline BRCA1 mutation analysis of 66 PC patients with 2 or more affected relatives detected no mutated cases [49]. As a second susceptibility gene, Jones et al. discovered a PALB2 frameshift variant (c.172_175 delTTGT) in one FPC patient by examining whole-exome sequencing data, and identified PALB2 truncation mutation leading to a stop codon in 3 of 96 (3.1\%) FPC cases, in comparison with no mutation in the control cohort of 1,084 [50]. Interestingly, the locations of mutations found in this study were different from those previously reported in familial breast cancer or Fanconi anemia [50,51]. Slater et al. also sequenced the 13 exons of the PALB2 gene for 81 FPC families, and identified truncating mutation leading to a stop codon in $3(3.7 \%)$ cases [52]. Furthermore, Roberts et al. discovered heterozygous ATM nonsense variants (c. 8266A>T; c.170G $>$ A) in 2 FPC kindreds from whole-genome or whole-exome sequencing data, and validated deleterious ATM mutations in 4 of $166(2.4 \%)$ FPC probands in comparison with no mutation in a control cohort [53]. When the subjects were restricted to 87 probands with more than three affected members, ATM mutation prevalence was 4.6\%. BRCA2, PALB2 and ATM are all involved in the HRR pathway. In brief, ATM is recruited in response to DNA double-strand breaks (DSBs) induced by DNA damage and activates CHK2. PALB2 promotes invasion of BRCA2-RAD51 complex into damaged DNA strands by localizing BRCA2 to DSBs [54].

Other genes are also suspected of association with FPC onset. In an Italian PC cohort including 16 FPC cases, Ghiorzo et al. found CDKN2A germline mutation in $31.3 \%$ of FPC patients without BRCA2 and PALB2 mutation [55]. Bartsch et al. detected 1100delC variant of CHEK2 in 2.9\% of German FPC families, and Lener et al. also found that relatives harboring this mutation had a 2.3-fold higher PC risk in a Polish cohort [56,57]. Furthermore, van der Heijden et al. or Couch et al. linked mutations in Fanconi anemia genes (FANCC and FANCG) with young onset PC [58,59]. Pogue-Geile et al. presented palladin (PALLD) encoding cytoskeletal component as a novel susceptibility gene, though this was not validated in subsequent studies [60,61]. Finally, Roberts et al. listed spindle-assembly checkpoint gene $B U B 1 B, C P A 1$ encoding carboxypeptidase A1, FANCC and FANCG as candidate susceptibility genes based on whole-genome sequencing data for 638 FPC patients [62]. Extensive further studies are required to reveal the functional impact of these genes in FPC. 


\section{Germline Mutation Prevalence in FPC Compared with Sporadic PC}

Information about germline mutation in FPC is essential for developing surveillance and treatment strategies, and there have been several studies along these lines (Table 2). According to a germline mutation analysis of four genes (BRCA1, BRCA2, PALB2 and CDKN2A) in 727 affected cases including $521 \mathrm{FPC}$, the percentage of cases harboring the above gene mutations was higher in FPC probands than in non-FPC probands ( $8.0 \%$ vs. $3.5 \%$ ) (odds ratio: $2.4,95 \%$ CI: $1.1-5.4$ ) [63]. In this study, the mutation prevalence in the FPC cohort was $3.7 \%$ for $B R C A 2,2.5 \%$ for $C D K N 2 A, 1.2 \%$ for $B R C A 1$, and $0.6 \%$ for $P A L B 2$. Grant et al. conducted targeted sequencing of 13 genes associated with hereditary cancer syndromes or FPC for 290 PC probands, and showed the mutation prevalence was $2.6 \%$ (95\% CI: 0-6.0) in cases with a history of PC in FDR and 4.0\% (95\% CI: 2.1-5.9) in those without any history [64]. Petersen et al. also conducted germline analysis of 25 cancer susceptibility genes for 303 PC patients including an FPC cohort in the Mayo Clinic Familial Pancreatic Cancer Registry, and reported that $12.9 \%$ of 186 FPC cases and $9.4 \%$ of 117 non-FPC cases harbored some mutations [65]. From a Japanese cohort of 1,197 PC patients, Takai et al. identified 88 (7.3\%) FPC cases, and conducted germline sequencing of hereditary cancer susceptibility genes [66]. In this study, deleterious mutations were detected in 8 of 54 (14.5\%) cases, including 3 (5.6\%) BRCA2 mutation, 2 (3.7\%) PALB2 mutation, 2 (3.7\%) ATM mutation and $1(1.9 \%)$ MLH1 mutation. These data indicate genomic heterogeneity in FPC, although inconsistencies in mutation prevalence among studies might be influenced by the number of target genes, limited sample size or subjects' backgrounds, including ethnicity. Importantly, previous studies found no susceptibility gene mutations in more than $80 \%$ of FPC cases, suggesting that further investigations to identify novel susceptibility genes should be fruitful.

Table 2. Germline mutation analyses for patients with FPC.

\begin{tabular}{ccccc}
\hline Author & $\begin{array}{c}\text { Number of } \\
\text { Analyzed Patients }\end{array}$ & $\begin{array}{c}\text { Number of } \\
\text { Targeted-Genes }\end{array}$ & $\begin{array}{c}\text { Mutation } \\
\text { Prevalence }\end{array}$ & Detected Gene Mutations \\
\hline Zhen, et al. [62] & 521 & 4 & $8.0 \%$ & $\begin{array}{c}\text { BRCA2 (3.7\%), CDKN2A (2.5\%), } \\
\text { BRCA1 (1.2\%), PALB2 (0.6\%) }\end{array}$ \\
\hline Grant, et al. [63] & 39 & 13 & $2.6 \%$ & ATM (2.6\%) \\
\hline Petersen, et al. [64] & 186 & 25 & $12.9 \%$ & NA \\
\hline Takai, et al. [65] & 54 & 21 & $14.5 \%$ & $\begin{array}{c}\text { BRCA2 (5.6\%), PALB2 (3.7\%), } \\
\text { ATM (3.7\%), MLH1 (1.9\%) }\end{array}$ \\
\hline
\end{tabular}

Germline mutations in cancer susceptibility genes are also found in cases without definite family history or association with hereditary syndromes. Hu et al. conducted germline analysis of 22 cancer susceptibility genes for 96 PC cases without preselection based on family history, and detected deleterious mutations in $13.5 \%$ of the cases, including $9.4 \%$ for four genes (BRCA1, BRCA2, ATM, and MSH6) [67]. Yurgelun et al. conducted targeted sequencing of 24 hereditary cancer susceptibility genes in a series of 289 resected PC, and detected mutations in $9.7 \%$ of the cases including $7.3 \%$ for HRR genes and 1.0\% for MMR genes [68]. Targeted sequencing of 32 genes in an unselected PC series of 854 cases revealed deleterious mutations in 3.9\% of the cases, including 3.5\% for 7 FPC-related genes [69]. $\mathrm{Hu}$ et al. recently compared genomic data of 3,030 affected cases and a normal cohort, and found that $5.5 \%$ of the affected cases harbored mutation in 6 genes associated with increased PC risk (CDKN2A, TP53, MLH1, BRCA1, BRCA2, and ATM) [70]. In the latest germline analysis of 298 unselected PC patients, $23(7.7 \%)$ patients harbored deleterious mutations in PC susceptibility genes [71]. In this study, 6 of $23(26.1 \%)$ mutated cases actually did not fulfill prescribed genetic testing criteria for hereditary cancer syndrome or FPC, and 12 of the 23 (52.2\%) mutated cases would not have been checked according to the criteria. These results indicate that the disparity in germline mutation prevalence between FPC and sporadic PC is not dramatic, and that current screening strategies chiefly based on family history cannot completely extract susceptibility gene carriers. On the other hand, exhaustive 
genomic analysis seems not to be cost-effective, since mutation is not so frequent. Here, software risk assessment tools based on family and past history of PC, such as PancPRO, might deserve further consideration [72].

\section{Surveillance Strategy for High-Risk Cases}

Considering the low incidence of PC, comprehensive surveillance for the general population is not recommended, and only cases with increased PC risk $>10$-fold or lifetime PC risk $>5 \%$ are considered as feasible candidates for surveillance $[4,73,74]$. The expert consensus practice recommendations formulated in the International Symposium of Inherited Diseases of the Pancreas in 2007 describe potential subjects for surveillance as follows: (1) individuals with PJS or hereditary pancreatitis; (2) $B R C A 1, B R C A 2$ or $C D K N 2 A$ mutation carriers with at least one affected first- or second-degree relative; (3) individuals with three or more affected first-degree, second-degree or third-degree relatives; and (4) individuals with two affected relatives including at least one FDR [73]. According to the recommendations of the International Cancer of the Pancreas Screening (CAPS) Consortium summit in 2013, surveillance for the following categories is recommended: (1) individuals with PJS; (2) CDKN2A, $B R C A 2$ or MMR gene mutation carriers with at least one affected FDR; and (3) individuals with at least two affected FDRs [74]. Remarkably, descriptions regarding family history are different between the two expert recommendations, and the later CAPS statements list MMR genes instead of BRCA1. There are no established protocols for screening modalities, follow-up duration, or time of screening initiation/termination, though Canto proposed a surveillance program by endoscopic ultrasound (EUS) and MRI at 1-3 year intervals from age 40 or from 10 years before the earliest age of PC onset in the family [75].

Vasen et al. selected 134 relatives with two affected FDRs, 80 relatives with at least three affected FDRs, 178 unaffected CDKN2A mutation carriers and 19 unaffected BRCA2/PALB2 mutation carriers from three cohorts in Europe, and prospectively monitored them as high-risk individuals using MRI (i.e., magnetic resonance cholangiopancreatography) or EUS [76]. Among CDKN2A mutation carriers, $13(7.3 \%)$ cases developed PC, and the clinical outcomes were favorable (75\% resection rate and $24 \%$ 5 -year overall survival (OS) rate). On the other hand, PC occurrence in the FPC cohort was low $(0.5 \%)$, and the authors concluded that the practical justification for conducting surveillance was not so robust for FPC as for CDKN2A mutation carriers. Canto et al. also followed-up 354 unaffected individuals categorized as a high-risk group based on three factors (designated gene mutation, PC family history, or age of PC onset) [77]. In this study, 10 subjects developed PC inside the surveillance program and 4 individuals outside the program, and the OS was significantly better in the former group (3-year OS rate: $85 \%$ vs. $25 \%$ ). According to a systematic review including five prospective controlled studies for familial high-risk individuals, subjects in a screening program, mainly by EUS, had a significantly higher curative resection rate (60\% vs. $25 \%$ ) and longer OS (median OS: 14.5 months vs. 4.0 months) compared with the control group, although psychological function and economic burden were adverse in the screening group [78]. Although the above clinical data are promising, pancreatic resection is a relatively invasive surgery, and the clinical benefit of PC surveillance for high-risk unaffected relatives is unclear owing to no randomized trials. Such programs should be provided as a clinical trial in experienced institutions [75].

\section{Medication for Patients Harboring Susceptibility Gene Mutations}

\subsection{Platinum-Based Regimen}

Several clinical trials have shown clinical benefits of a platinum-based initial regimen, especially for $B R C A$-mutated cases. Golan et al. reviewed clinical outcomes in a series of 71 PC patients harboring $B R C A 1 / B R C A 2$ mutation, and reported that stage $3 / 4$ patients receiving a platinum regimen had significantly longer OS than those receiving a non-platinum regimen (median OS: 22 months vs. 9 months) [79]. In this study, the combination of gemcitabine (GEM) plus cisplatin (CDDP) was mainly 
adopted as the platinum regimen. According to a retrospective review of 36 metastatic PC patients receiving the leucovorin calcium, fluorouracil, irinotecan hydrochloride and oxaliplatin (FOLFIRINOX) regimen, cases harboring mutations in DNA damage repair (DDR) genes (BRCA1, BRCA2, PALB2, $M S H 2$ and $F A N C F$ ) had marginally longer OS than those without the mutations (median OS: 14 months vs. 5 months), and multivariate analysis showed a significant association between DDR gene mutation status and longer OS [80]. The latest NCCN Guidelines for PC describe GEM/CDDP as one of the first-line options for known BRCA1/BRCA2-mutated cases [81]. Recently, Takahashi et al. presented phase II trial data of the GEM plus oxaliplatin (GEMOX) regimen as a first-line treatment for PC cases [82]. This trial enrolling patients based on personal or family history of pancreatic, breast, ovarian and prostate cancers failed to demonstrate a promising survival benefit (1-year OS rate: $27.9 \%$, which suggests that personal/family history alone might be insufficient for selecting suitable candidates. Randomized trials are needed to establish the position of platinum-based regimens.

\subsection{PARP Inhibitors}

PARP inhibitors have been clinically investigated for BRCA-mutated cases as second-line or later treatments (Table 3). This class of agents mechanically inhibits participation of PARP in base excision repair, and causes DSBs due to unrepaired single-strand breaks [83]. DSBs are usually restored by the HRR pathway, whereas BRCA protein deficiency deriving from inactivating BRCA1/BRCA2 mutation inhibits this pathway and finally induces cell death $[84,85]$.

Table 3. Clinical trials of PARP inhibitor for PC patients harboring BRCA1/BRCA2 mutation.

\begin{tabular}{cccccccc}
\hline \multicolumn{1}{c}{ Author } & Agent & Phase & $\begin{array}{c}\text { Number of } \\
\text { Patients }\end{array}$ & $\begin{array}{c}\text { Disease } \\
\text { Status }\end{array}$ & ORR & OS & PFS \\
\hline Kaufman et al. [84] & Olaparib & II & 23 & Advanced & $21.7 \%$ & 9.8 months & 4.6 months \\
\hline Shroff et al. [85] & Rucaparib & II & 19 & $\begin{array}{c}\text { Locally } \\
\text { advanced, } \\
\text { Metastatic }\end{array}$ & $21.1 \%$ & NA & NA \\
\hline Lowery et al. [86] & Veliparib & II & 16 & $\begin{array}{c}\text { Locally } \\
\text { advanced, } \\
\text { Metastatic }\end{array}$ & $0 \%$ & 3.1 months & 1.7 months \\
\hline de Bono et al. [87] & Talazoparib & I & 10 & Advanced & $20.0 \%$ & NA & NA \\
\hline O'Reilly et al. [88] & $\begin{array}{l}\text { Veliparib plus } \\
\text { GEM/CDDP }\end{array}$ & I & 9 & $\begin{array}{c}\text { Locally } \\
\text { advanced, } \\
\text { Metastatic }\end{array}$ & $77.8 \%$ & 23.3 months & NA \\
\hline
\end{tabular}

ORR, overall response rate; OS, overall survival; PFS, progression-free survival; GEM, gemcitabine; CDDP, cisplatin; NA, not available.

Kaufman et al. conducted a phase II trial of olaparib for 298 patients with advanced BRCA1 / BRCA2-mutated tumors including 23 PC cases [86]. Overall response rate (ORR) was $26.2 \%$ in the entire cohort and $21.7 \%$ in the PC cohort, and median OS and progression-free survival (PFS) in the PC cohort were 9.8 months and 4.6 months, respectively. The outcomes seem promising for relapsed PC, and this trial has become the foundation for further clinical trials. Shroff et al. performed a phase II trial of rucaparib (RUCAPANC trial) for 19 patients with locally advanced/metastatic PC harboring BRCA1/BRCA2 mutation, and reported an ORR of $21.1 \%$ and disease control rate of $31.6 \%$ [87]. According to another phase II trial of veliparib for 16 PC patients with BRCA1/BRCA2 mutation, no patient achieved a response, and the median OS and PFS were only 3.1 months and 1.7 months, respectively [88]. The modest efficacy of veliparib as a single agent compared with olaparib or rucaparib is explained by its lower PARP-trapping activity, and combination therapies with cytotoxic agents are expected to become the mainstream of its clinical development [54]. de Bono et al. conducted a phase I trial of talazoparib, which exhibits the strongest PARP-trapping activity for patients with advanced malignancies, and reported that the ORR at $1.0 \mathrm{mg} / \mathrm{kg}$ (recommended phase II dose) was 
$22.2 \%$ in the entire cohort and $20.0 \%$ in 10 PC patients [89]. Out of two PC cases that achieved a partial response in this trial, one case harbored BRCA2 mutation and the other, PALB2 mutation.

Currently, several clinical trials of PARP inhibitors are underway for advanced PC. Firstly, a phase II trial of rucaparib for locally advanced/metastatic PC cases harboring BRCA1, BRCA2 or PALB2 mutation is in progress in the Abramson Cancer Center of the University of Pennsylvania, where the clinical efficacy of rucaparib maintenance therapy is being assessed following a platinum-based induction regimen of at least 16 weeks (NCT03140670). In a phase III trial of olaparib (POLO trial), metastatic PC patients with germline BRCA1/BRCA2 mutation who do not experience disease progression after a platinum-based regimen for 16 weeks or more are randomized to olaparib $300 \mathrm{mg}$ twice daily or placebo (NCT02184195). To evaluate combination therapy with a PARP inhibitor, O'Reilly et al. conducted a phase I trial of GEM/CDDP plus veliparib for 17 patients with untreated advanced PC, including 9 cases harboring germline $B R C A 1 / B R C A 2$ mutation, and reported an ORR of $77.8 \%$ and median OS of 23.3 months in BRCA-mutated cases [90]. Based on this promising outcome, a randomized phase II trial of GEM/CDDP with or without veliparib is being performed for locally advanced/metastatic PC cases with BRCA1, BRCA2 or PALB2 mutation (NCT01585805). Currently available evidence for this class of agents is for second-line or later treatment, and the above two randomized trials are expected to provide informative data for initial therapy [91].

Some BRCA-proficient tumors have defects in HRR genes including ATM, ATR, CHK1, CHK2, $P A L B 2$ and RAD51, and these cases, which share the molecular features of BRCA-mutant tumors (BRCAness) are considered as good targets for PARP inhibitor treatment [92,93]. Currently, phase II trials of olaparib for BRCAness phenotypic PC are in progress in the M.D. Anderson Cancer Center (NCT02677038) and Sheba Medical Center (NCT02511223).

\subsection{Immune Checkpoint Inhibitors}

While immune checkpoint inhibitors have provided striking clinical benefits for several kinds of malignancies, such as melanoma or non-small-cell lung cancer (NSCLC), the impact of this class of agents on PC as a whole is not evident. The presence of fewer neoantigens than melanoma and NSCLC, and a microenvironment composed of decreased intra-tumoral effector T-cells, increased immunosuppressive immune cells, and abundant extracellular matrix mechanically complicate clinical applications for PC [94,95]. Actually, a phase I trial of anti-PD-L1 antibody identified no responders in a 14 PC cohort in contrast to an ORR of $17 \%$ in melanoma or $10 \%$ in NSCLC [96].

Previous studies have demonstrated that patients with MMR-deficient colorectal cancer are favorable candidates for immune checkpoint blockade, and screening of MMR-deficient tumors is performed for various kinds of malignancies over colorectal cancer [97,98]. Le et al. evaluated the clinical efficacy of anti-PD-L1 antibody, pembrolizumab, for 86 relapsed patients with MMR-deficient tumors from 12 types of malignancies, including 8 PC patients. They reported that the ORR was $53.4 \%$ in the entire cohort and $62.5 \%$ in the PC cohort, and the complete response (CR) rate was $20.9 \%$ in the former and $25.0 \%$ in the latter [99]. The higher response in the PC cohort might be associated with a high mutation burden leading to increased neoantigens or active lymphocyte infiltrates in MMR-deficient tumors [97]. In 2017, the U.S. Food and Drug Administration (FDA) granted accelerated approval to pembrolizumab for patients with advanced MSI-high or MMR-deficient solid tumors, including PC [100].

Here, it should be noted that MMR-deficiency is caused by somatic mutations as well as germline mutations in MMR genes. Humphris et al. immunohistochemically identified 4 MMR-deficient cases from a cohort of 385 sporadic PC patients, and showed that all 4 patients harbored somatic mutations in $M L H 1$ or $M S H 2$ without germline mutation [101]. This result highlights the need for screening strategies to find MMR-deficient cases among seemingly sporadic tumors. 


\section{Conclusions and Future Prospects}

The overall genomic features and clinical management of hereditary PC syndromes and FPC are summarized in Figure 1. Patients with hereditary cancer syndromes exhibit unique clinical features from a younger age dependent on the particular syndrome, and harbor a specific causative gene. On the other hand, clinical features in FPC cases are ordinary and their genomic backgrounds are heterogenous. The rapid progress in genomic analysis has led to the discovery of several FPC susceptibility genes, such as BRCA2, PALB2 and ATM, and investigations to identify further genes are underway.

\begin{tabular}{|c|c|c|}
\hline $\begin{array}{l}\text { Genomic analysis } \\
\text { - } \quad \text { Discovery of FPC susceptibility } \\
\text { genes (BRCA2, PALB2, ATM) } \\
\text { - Heterogenous genetic } \\
\text { background in FPC cases } \\
\text { - Unsatisfactory identification of } \\
\text { susceptibility gene carriers } \\
\text { based on family history }\end{array}$ & $\begin{array}{l}\text { Surveillance for high-risk } \\
\text { unaffected cases } \\
\text { - No established surveillance } \\
\text { procedures } \\
\text { - Promising data in patients } \\
\text { developing PC and receiving } \\
\text { surgery inside surveillance } \\
\text { program }\end{array}$ & $\begin{array}{l}\text { Medication } \\
\text { - Favorable outcomes of PARP } \\
\text { inhibitor or immune checkpoint } \\
\text { inhibitor on second- or later } \\
\text { lines in single-arm phase I/II } \\
\text { trials } \\
\text { - Different clinical efficacy } \\
\text { between each PARP inhibitor }\end{array}$ \\
\hline
\end{tabular}

Future investigations

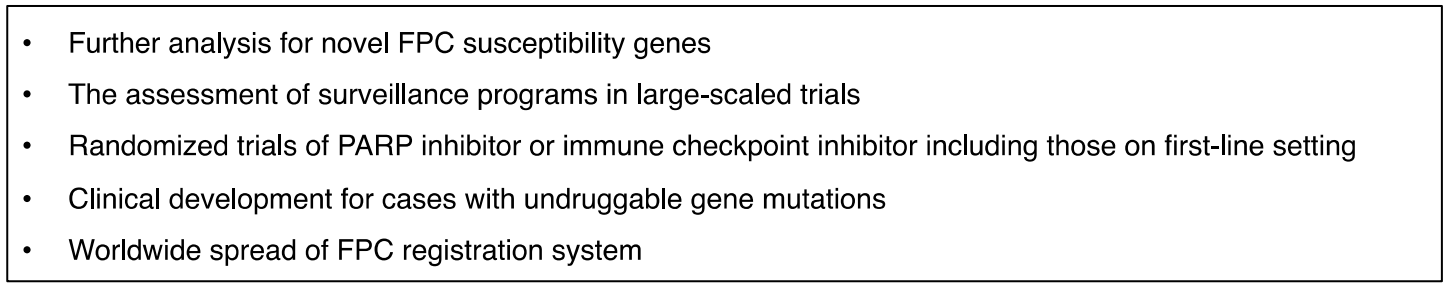

Figure 1. Current status and future prospects for hereditary PC syndromes and FPC from the viewpoints of genomic analysis, surveillance and medication.

Exhaustive genomic analyses have shown that surveillance based mainly on family history cannot pick up all susceptibility gene carriers, and more efficient approaches including software risk assessment tools or the use of artificial intelligence are needed. Regardless of some favorable data, the clinical benefits of surveillance programs have not been demonstrated in large-scale trials, and further trials are awaited. In terms of medication, PARP inhibitors for BRCA-mutated cases are in the frontline of clinical developments for PC. Randomized trials of olaparib alone or veliparib in combination with cytotoxic agents are underway, and these results are expected to establish the clinical position of PARP inhibitors. In addition, a clinical trial of anti-PD-1 antibody found a marked response for patients with MMR-deficient PC, and further investigation in a larger cohort seems worthwhile.

For the future, there are various avenues to explore. First of all, FPC is an entity especially based on family history, and the genetic backgrounds of these patients are heterogenous, unlike hereditary PC syndromes. Therefore, further discussion is required to treat it as a type of hereditary PC. Secondly, most of the mutations detected in genomic analysis are still undruggable, so development of novel agents is indispensable to link available genomic information with improved outcomes [102,103]. Thirdly, early diagnosis is one of the major goals of surveillance for high-risk cases, though specific approaches for each detected finding remain to be established. Fourthly, the arrival of novel agents presents the practical problem of how to properly use these agents together with conventional cytotoxic agents such as platinum drugs, depending on disease status. Finally, clinical and genomic data about hereditary PC are still limited, especially for non-western populations, and the worldwide spread of the FPC registration system founded in 1994 in the US is expected to provide a solid foundation for future investigations [104]. 
Funding: This research received no external funding.

Conflicts of Interest: The authors declare no competing financial interests.

\section{References}

1. American Cancer Society. Five-Year Survival Rate Comes from SEER-9 Data. Cancer Facts \& Figures 2018. Available online: https:/ / www.pancan.org/facing-pancreatic-cancer/about-pancreatic-cancer/survivalrate/ (accessed on 28 September 2018).

2. Bray, F.; Ferlay, J.; Soerjomataram, I.; Siegel, R.L.; Torre, L.A.; Jemal, A. Global cancer statistics 2018: GLOBOCAN estimates of incidence and mortality worldwide for 36 cancers in 185 countries. CA Cancer J. Clin. 2018, 68, 394-424. [CrossRef] [PubMed]

3. Klein, A.P. Genetic susceptibility to pancreatic cancer. Mol. Carcinog. 2012, 51, 14-24. [CrossRef] [PubMed]

4. Welinsky, S.; Lucas, A.L. Familial pancreatic cancer and the future of directed screening. Gut Liver 2017, 11, 761-770. [CrossRef]

5. Steinberg, W.M.; Barkin, J.S.; Bradley, E.L., 3rd; DiMagno, E.; Layer, P.; Canto, M.I.; Levy, M.J. Should patients with a strong family history of pancreatic cancer be screened on a periodic basis for cancer of the pancreas? Pancreas 2009, 38, e137-e150. [CrossRef]

6. Syngal, S.; Brand, R.E.; Church, J.M.; Giardiello, F.M.; Hampel, H.L.; Burt, R.W.; American College of Gastroenterology. ACG clinical guideline: Genetic testing and management of hereditary gastrointestinal cancer syndromes. Am. J. Gastroenterol. 2015, 110, 223-262. [CrossRef]

7. Shi, C.; Hruban, R.H.; Klein, A.P. Familial pancreatic cancer. Arch. Pathol. Lab. Med. 2009, 133, $365-374$. [CrossRef] [PubMed]

8. Zhan, W.; Shelton, C.A.; Greer, P.J.; Brand, R.E.; Whitcomb, D.C. Germline variants and risk for pancreatic cancer: A systematic review and emerging concepts. Pancreas 2018, 47, 924-936. [CrossRef]

9. Giardiello, F.M.; Brensinger, J.D.; Tersmette, A.C.; Goodman, S.N.; Petersen, G.M.; Booker, S.V.; Cruz-Correa, M.; Offerhaus, J.A. Very high risk of cancer in familial Peutz-Jeghers syndrome. Gastroenterology 2000, 119, 1447-1453. [CrossRef] [PubMed]

10. Hearle, N.; Schumacher, V.; Menko, F.H.; Olschwang, S.; Boardman, L.A.; Gille, J.J.; Keller, J.J.; Westerman, A.M.; Scott, R.J.; Lim, W.; et al. Frequency and spectrum of cancers in the Peutz-Jeghers syndrome. Clin. Cancer Res. 2006, 12, 3209-3215. [CrossRef]

11. Lim, W.; Olschwang, S.; Keller, J.J.; Westerman, A.M.; Menko, F.H.; Boardman, L.A.; Scott, R.J.; Trimbath, J.; Giardiello, F.M.; Gruber, S.B.; et al. Relative frequency and morphology of cancers in STK11 mutation carriers. Gastroenterology 2004, 126, 1788-1794. [CrossRef]

12. Greer, J.B.; Lynch, H.T.; Brand, R.E. Hereditary pancreatic cancer: A clinical perspective. Best Pract. Res. Clin. Gastroenterol. 2009, 23, 159-170. [CrossRef]

13. Rustgi, A.K. Familial pancreatic cancer: Genetic advances. Genes Dev. 2014, 28, 1-7. [CrossRef] [PubMed]

14. Lowenfels, A.B.; Maisonneuve, P.; DiMagno, E.P.; Elitsur, Y.; Gates, L.K., Jr.; Perrault, J.; Whitcomb, D.C. Hereditary pancreatitis and the risk of pancreatic cancer. International Hereditary PancreatitisStudy Group. J. Natl. Cancer Inst. 1997, 89, 442-446. [CrossRef] [PubMed]

15. Rebours, V.; Boutron-Ruault, M.C.; Schnee, M.; Férec, C.; Maire, F.; Hammel, P.; Ruszniewski, P.; Lévy, P. Risk of pancreatic adenocarcinoma in patients with hereditary pancreatitis: A national exhaustive series. Am. J. Gastroenterol. 2008, 103, 111-119. [CrossRef]

16. Shelton, C.A.; Umapathy, C.; Stello, K.; Yadav, D.; Whitcomb, D.C. Hereditary pancreatitis in the United States: Survival and rates of pancreatic cancer. Am. J. Gastroenterol. 2018, 113, 1376-1384. [CrossRef] [PubMed]

17. Oracz, G.; Kolodziejczyk, E.; Sobczynska-Tomaszewska, A.; Wejnarska, K.; Dadalski, M.; Grabarczyk, A.M.; Kierkus, J.; Woynarowski, M.; Wertheim-Tysarowska, K.; Ryzko, J.; et al. The clinical course of hereditary pancreatitis in children-A comprehensive analysis of 41 cases. Pancreatology 2016, 16, 535-541. [CrossRef]

18. Rebours, V.; Boutron-Ruault, M.C.; Schnee, M.; Férec, C.; Le Maréchal, C.; Hentic, O.; Maire, F.; Hammel, P.; Ruszniewski, P.; Lévy, P. The natural history of hereditary pancreatitis: A national series. Gut 2009, 58, 97-103. [CrossRef] 
19. Masamune, A.; Kikuta, K.; Hamada, S.; Nakano, E.; Kume, K.; Inui, A.; Shimizu, T.; Takeyama, Y.; Nio, M.; Shimosegawa, T. Nationwide survey of hereditary pancreatitis in Japan. J. Gastroenterol. 2018, 53, $152-160$. [CrossRef]

20. Hruban, R.H.; Canto, M.I.; Goggins, M.; Schulick, R.; Klein, A.P. Update on familial pancreatic cancer. Adv. Surg. 2010, 44, 293-311. [CrossRef]

21. Vasen, H.F.; Gruis, N.A.; Frants, R.R.; van Der Velden, P.A.; Hille, E.T.; Bergman, W. Risk of developing pancreatic cancer in families with familial atypical multiple mole melanoma associated with a specific 19 deletion of p16 (p16-Leiden). Int. J. Cancer 2000, 87, 809-811. [CrossRef]

22. Goldstein, A.M.; Fraser, M.C.; Struewing, J.P.; Hussussian, C.J.; Ranade, K.; Zametkin, D.P.; Fontaine, L.S.; Organic, S.M.; Dracopoli, N.C.; Clark, W.H., Jr.; et al. Increased risk of pancreatic cancer in melanoma-prone kindreds with p16INK4 mutations. N. Engl. J. Med. 1995, 333, 970-974. [CrossRef]

23. De Snoo, F.A.; Bishop, D.T.; Bergman, W.; van Leeuwen, I.; van der Drift, C.; van Nieuwpoort, F.A.; Out-Luiting, C.J.; Vasen, H.F.; ter Huurne, J.A.; Frants, R.R.; et al. Increased risk of cancer other than melanoma in CDKN2A founder mutation (p16-Leiden)-positive melanoma families. Clin. Cancer Res. 2008, 14, 7151-7157. [CrossRef] [PubMed]

24. Lynch, H.T.; Shaw, T.G. Familial atypical multiple mole melanoma (FAMMM) syndrome: History, genetics, and heterogeneity. Fam. Cancer 2016, 15, 487-491. [CrossRef] [PubMed]

25. Vasen, H.F.; Wasser, M.; van Mil, A.; Tollenaar, R.A.; Konstantinovski, M.; Gruis, N.A.; Bergman, W.; Hes, F.J.; Hommes, D.W.; Offerhaus, G.J.; et al. Magnetic resonance imaging surveillance detects early-stage pancreatic cancer in carriers of a p16-Leiden mutation. Gastroenterology 2011, 140, 850-856. [CrossRef] [PubMed]

26. Becker, A.E.; Hernandez, Y.G.; Frucht, H.; Lucas, A.L. Pancreatic ductal adenocarcinoma: Risk factors, screening, and early detection. World J. Gastroenterol. 2014, 20, 11182-11198. [CrossRef]

27. Giardiello, F.M.; Offerhaus, G.J.; Lee, D.H.; Krush, A.J.; Tersmette, A.C.; Booker, S.V.; Kelley, N.C.; Hamilton, S.R. Increased risk of thyroid and pancreatic carcinoma in familial adenomatous polyposis. Gut 1993, 34, 1394-1396. [CrossRef] [PubMed]

28. Moussata, D.; Senouci, L.; Berger, F.; Scoazec, J.Y.; Pinson, S.; Walter, T.; Lombard-Bohas, C.; Saurin, J.C. Familial adenomatous polyposis and pancreatic cancer. Pancreas 2015, 44, 512-513. [CrossRef]

29. Abraham, S.C.; Wu, T.T.; Klimstra, D.S.; Finn, L.S.; Lee, J.H.; Yeo, C.J.; Cameron, J.L.; Hruban, R.H. Distinctive molecular genetic alterations in sporadic and familial adenomatous polyposis-associated pancreatoblastomas: Frequent alterations in the APC/beta-catenin pathway and chromosome 11p. Am. J. Pathol. 2001, 159, 1619-1627. [CrossRef]

30. Kuiper, R.P.; Vissers, L.E.; Venkatachalam, R.; Bodmer, D.; Hoenselaar, E.; Goossens, M.; Haufe, A.; Kamping, E.; Niessen, R.C.; Hogervorst, F.B.; et al. Recurrence and variability of germline EPCAM deletions in Lynch syndrome. Hum. Mutat. 2011, 32, 407-414. [CrossRef]

31. Umar, A.; Boland, C.R.; Terdiman, J.P.; Syngal, S.; de la Chapelle, A.; Rüschoff, J.; Fishel, R.; Lindor, N.M.; Burgart, L.J.; Hamelin, R.; et al. Revised Bethesda Guidelines for hereditary nonpolyposis colorectal cancer (Lynch syndrome) and microsatellite instability. J. Natl. Cancer Inst. 2004, 96, 261-268. [CrossRef]

32. Kastrinos, F.; Mukherjee, B.; Tayob, N.; Wang, F.; Sparr, J.; Raymond, V.M.; Bandipalliam, P.; Stoffel, E.M.; Gruber, S.B.; Syngal, S. Risk of pancreatic cancer in families with Lynch syndrome. JAMA 2009, 302, 1790-1795. [CrossRef]

33. Møller, P.; Seppälä, T.T.; Bernstein, I.; Holinski-Feder, E.; Sala, P.; Gareth Evans, D.; Lindblom, A.; Macrae, F.; Blanco, I.; Sijmons, R.H.; et al. Cancer risk and survival in path_MMR carriers by gene and gender up to 75 years of age: A report from the Prospective Lynch Syndrome Database. Gut 2018, 67, 1306-1316. [CrossRef] [PubMed]

34. Ohmoto, A.; Morizane, C.; Kubo, E.; Takai, E.; Hosoi, H.; Sakamoto, Y.; Kondo, S.; Ueno, H.; Shimada, K.; Yachida, S.; et al. Germline variants in pancreatic cancer patients with a personal or family history of cancer fulfilling the revised Bethesda guidelines. J. Gastroenterol. 2018, 53, 1159-1167. [CrossRef] [PubMed]

35. Hu, Z.I.; Shia, J.; Stadler, Z.K.; Varghese, A.M.; Capanu, M.; Salo-Mullen, E.; Lowery, M.A.; Diaz, L.A., Jr.; Mandelker, D.; Yu, K.H.; et al. Evaluating mismatch repair deficiency in pancreatic adenocarcinoma: Challenges and recommendations. Clin. Cancer Res. 2018, 24, 1326-1336. [CrossRef] [PubMed]

36. Yurgelun, M.B.; Hampel, H. Recent advances in lynch syndrome: Diagnosis, treatment, and cancer prevention. Am. Soc. Clin. Oncol. Educ. Book 2018, 38, 101-109. [CrossRef] [PubMed] 
37. Yamauchi, H.; Takei, J. Management of hereditary breast and ovarian cancer. Int. J. Clin. Oncol. 2018, 23, 45-51. [CrossRef]

38. Centers for Disease Control and Prevention. HBOC Syndrome. Inside Knowledge about Gynecologic Cancer. Available online: https://www.cdc.gov/cancer/knowledge/provider-education/genetics/hboc-syndrome. htm (accessed on 25 December 2018).

39. Lynch, H.T.; Deters, C.A.; Snyder, C.L.; Lynch, J.F.; Villeneuve, P.; Silberstein, J.; Martin, H.; Narod, S.A.; Brand, R.E. BRCA1 and pancreatic cancer: Pedigree findings and their causal relationships. Cancer Genet Cytogenet. 2005, 158, 119-125. [CrossRef]

40. Iqbal, J.; Ragone, A.; Lubinski, J.; Lynch, H.T.; Moller, P.; Ghadirian, P.; Foulkes, W.D.; Armel, S.; Eisen, A.; Neuhausen, S.L.; et al. The incidence of pancreatic cancer in BRCA1 and BRCA2 mutation carriers. Br. J. Cancer 2012, 107, 2005-2009. [CrossRef]

41. Mersch, J.; Jackson, M.A.; Park, M.; Nebgen, D.; Peterson, S.K.; Singletary, C.; Arun, B.K.; Litton, J.K. Cancers associated with BRCA1 and BRCA2 mutations other than breast and ovarian. Cancer 2015, 121, 269-275. [CrossRef]

42. Singhi, A.D.; Ishida, H.; Ali, S.Z.; Goggins, M.; Canto, M.; Wolfgang, C.; Meriden, Z.; Roberts, N.; Klein, A.P.; Hruban, R.H. A histomorphologic comparison of familial and sporadic pancreatic cancers. Pancreatology 2015, 15, 387-391. [CrossRef]

43. Klein, A.P.; Brune, K.A.; Petersen, G.M.; Goggins, M.; Tersmette, A.C.; Offerhaus, G.J.; Griffin, C.; Cameron, J.L.; Yeo, C.J.; Kern, S.; et al. Prospective risk of pancreatic cancer in familial pancreatic cancer kindreds. Cancer Res. 2004, 64, 2634-2638. [CrossRef] [PubMed]

44. Permuth-Wey, J.; Egan, K.M. Family history is a significant risk factor for pancreatic cancer: Results from a systematic review and meta-analysis. Fam. Cancer 2009, 8, 109-117. [CrossRef] [PubMed]

45. Jacobs, E.J.; Chanock, S.J.; Fuchs, C.S.; Lacroix, A.; McWilliams, R.R.; Steplowski, E.; Stolzenberg-Solomon, R.Z.; Arslan, A.A.; Bueno-de-Mesquita, H.B.; Gross, M.; et al. Family history of cancer and risk of pancreatic cancer: A pooled analysis from the Pancreatic Cancer Cohort Consortium (PanScan). Int. J. Cancer 2010, 127, 1421-1428. [CrossRef] [PubMed]

46. Murphy, K.M.; Brune, K.A.; Griffin, C.; Sollenberger, J.E.; Petersen, G.M.; Bansal, R.; Hruban, R.H.; Kern, S.E. Evaluation of candidate genes MAP2K4, MADH4, ACVR1B, and BRCA2 in familial pancreatic cancer: Deleterious BRCA2 mutations in 17\%. Cancer Res. 2002, 62, 3789-3793. [PubMed]

47. Hahn, S.A.; Greenhalf, B.; Ellis, I.; Sina-Frey, M.; Rieder, H.; Korte, B.; Gerdes, B.; Kress, R.; Ziegler, A.; Raeburn, J.A.; et al. BRCA2 germline mutations in familial pancreatic carcinoma. J. Natl. Cancer Inst. 2003, 95, 214-221. [CrossRef] [PubMed]

48. Struewing, J.P.; Hartge, P.; Wacholder, S.; Baker, S.M.; Berlin, M.; McAdams, M.; Timmerman, M.M.; Brody, L.C.; Tucker, M.A. The risk of cancer associated with specific mutations of BRCA1 and BRCA2 among Ashkenazi Jews. N. Engl. J. Med. 1997, 336, 1401-1408. [CrossRef]

49. Axilbund, J.E.; Argani, P.; Kamiyama, M.; Palmisano, E.; Raben, M.; Borges, M.; Brune, K.A.; Goggins, M.; Hruban, R.H.; Klein, A.P. Absence of germline BRCA1 mutations in familial pancreatic cancer patients. Cancer Biol. Ther. 2009, 8, 131-135. [CrossRef]

50. Jones, S.; Hruban, R.H.; Kamiyama, M.; Borges, M.; Zhang, X.; Parsons, D.W.; Lin, J.C.; Palmisano, E.; Brune, K.; Jaffee, E.M.; et al. Exomic sequencing identifies PALB2 as a pancreatic cancer susceptibility gene. Science 2009, 324, 217. [CrossRef]

51. Rahman, N.; Seal, S.; Thompson, D.; Kelly, P.; Renwick, A.; Elliott, A.; Reid, S.; Spanova, K.; Barfoot, R.; Chagtai, T.; et al. PALB2, which encodes a BRCA2-interacting protein, is a breast cancer susceptibility gene. Nat. Genet. 2007, 39, 165-167. [CrossRef]

52. Slater, E.P.; Langer, P.; Niemczyk, E.; Strauch, K.; Butler, J.; Habbe, N.; Neoptolemos, J.P.; Greenhalf, W.; Bartsch, D.K. PALB2 mutations in European familial pancreatic cancer families. Clin. Genet. 2010, 78, 490-494. [CrossRef]

53. Roberts, N.J.; Jiao, Y.; Yu, J.; Kopelovich, L.; Petersen, G.M.; Bondy, M.L.; Gallinger, S.; Schwartz, A.G.; Syngal, S.; Cote, M.L.; et al. ATM mutations in patients with hereditary pancreatic cancer. Cancer Discov. 2012, 2, 41-46. [CrossRef] [PubMed]

54. Ohmoto, A.; Yachida, S. Current status of poly(ADP-ribose) polymerase inhibitors and future directions. Onco Targets Ther. 2017, 10, 5195-5208. [CrossRef] [PubMed] 
55. Ghiorzo, P.; Fornarini, G.; Sciallero, S.; Battistuzzi, L.; Belli, F.; Bernard, L.; Bonelli, L.; Borgonovo, G.; Bruno, W.; De Cian, F.; et al. CDKN2A is the main susceptibility gene in Italian pancreatic cancer families. J. Med. Genet. 2012, 49, 164-170. [CrossRef] [PubMed]

56. Bartsch, D.K.; Krysewski, K.; Sina-Frey, M.; Fendrich, V.; Rieder, H.; Langer, P.; Kress, R.; Schneider, M.; Hahn, S.A.; Slater, E.P. Low frequency of CHEK2 mutations in familial pancreatic cancer. Fam. Cancer 2006, 5, 305-308. [CrossRef] [PubMed]

57. Lener, M.R.; Kashyap, A.; Kluźniak, W.; Cybulski, C.; Soluch, A.; Pietrzak, S.; Huzarski, T.; Gronwald, J.; Lubiński, J. The prevalence of founder mutations among individuals from families with familial pancreatic cancer syndrome. Cancer Res. Treat. 2017, 49, 430-436. [CrossRef]

58. Van der Heijden, M.S.; Yeo, C.J.; Hruban, R.H.; Kern, S.E. Fanconi anemia gene mutations in young-onset pancreatic cancer. Cancer Res. 2003, 63, 2585-2588.

59. Couch, F.J.; Johnson, M.R.; Rabe, K.; Boardman, L.; McWilliams, R.; de Andrade, M.; Petersen, G. Germ line Fanconi anemia complementation group C mutations and pancreatic cancer. Cancer Res. 2005, 65, 383-386.

60. Pogue-Geile, K.L.; Chen, R.; Bronner, M.P.; Crnogorac-Jurcevic, T.; Moyes, K.W.; Dowen, S.; Otey, C.A.; Crispin, D.A.; George, R.D.; Whitcomb, D.C.; et al. Palladin mutation causes familial pancreatic cancer and suggests a new cancer mechanism. PLoS Med. 2006, 3, e516. [CrossRef]

61. Slater, E.; Amrillaeva, V.; Fendrich, V.; Bartsch, D.; Earl, J.; Vitone, L.J.; Neoptolemos, J.P.; Greenhalf, W. Palladin mutation causes familial pancreatic cancer: Absence in European families. PLoS Med. 2007, 4, e164. [CrossRef]

62. Roberts, N.J.; Norris, A.L.; Petersen, G.M.; Bondy, M.L.; Brand, R.; Gallinger, S.; Kurtz, R.C.; Olson, S.H.; Rustgi, A.K.; Schwartz, A.G.; et al. Whole genome sequencing defines the genetic heterogeneity of familial pancreatic cancer. Cancer Discov. 2016, 6, 166-175. [CrossRef]

63. Zhen, D.B.; Rabe, K.G.; Gallinger, S.; Syngal, S.; Schwartz, A.G.; Goggins, M.G.; Hruban, R.H.; Cote, M.L.; McWilliams, R.R.; Roberts, N.J.; et al. BRCA1, BRCA2, PALB2, and CDKN2A mutations in familial pancreatic cancer: A PACGENE study. Genet. Med. 2015, 17, 569-577. [CrossRef] [PubMed]

64. Grant, R.C.; Selander, I.; Connor, A.A.; Selvarajah, S.; Borgida, A.; Briollais, L.; Petersen, G.M.; Lerner-Ellis, J.; Holter, S.; Gallinger, S. Prevalence of germline mutations in cancer predisposition genes in patients with pancreatic cancer. Gastroenterology 2015, 148, 556-564. [CrossRef]

65. Petersen, G.M.; Chaffee, K.G.; McWilliams, R.R.; Majithia, N.; Allen, B.; Kidd, J.; Singh, N.; Hartman, A.R.; Oberg, A. Genetic heterogeneity and survival among pancreatic adenocarcinoma (PDAC) patients with positive family history. J. Clin. Oncol. 2016, 34. [CrossRef]

66. Takai, E.; Yachida, S.; Shimizu, K.; Furuse, J.; Kubo, E.; Ohmoto, A.; Suzuki, M.; Hruban, R.H.; Okusaka, T.; Morizane, C.; et al. Germline mutations in Japanese familial pancreatic cancer patients. Oncotarget 2016, 7, 74227-74235. [CrossRef] [PubMed]

67. Hu, C.; Hart, S.N.; Bamlet, W.R.; Moore, R.M.; Nandakumar, K.; Eckloff, B.W.; Lee, Y.K.; Petersen, G.M.; McWilliams, R.R.; Couch, F.J. Prevalence of pathogenic mutations in cancer predisposition genes among pancreatic cancer patients. Cancer Epidemiol. Biomark. Prev. 2016, 25, 207-211. [CrossRef] [PubMed]

68. Yurgelun, M.B.; Chittenden, A.B.; Morales-Oyarvide, V.; Rubinson, D.A.; Dunne, R.F.; Kozak, M.M.; Qian, Z.R.; Welch, M.W.; Brais, L.K.; Da Silva, A.; et al. Germline cancer susceptibility gene variants, somatic second hits, and survival outcomes inpatients with resected pancreatic cancer. Genet. Med. 2018. [CrossRef]

69. Shindo, K.; Yu, J.; Suenaga, M.; Fesharakizadeh, S.; Cho, C.; Macgregor-Das, A.; Siddiqui, A.; Witmer, P.D.; Tamura, K.; Song, T.J.; et al. Deleterious germline mutations in patients with apparently sporadic pancreatic adenocarcinoma. J. Clin. Oncol. 2017, 35, 3382-3390. [CrossRef]

70. Hu, C.; Hart, S.N.; Polley, E.C.; Gnanaolivu, R.; Shimelis, H.; Lee, K.Y.; Lilyquist, J.; Na, J.; Moore, R.; Antwi, S.O.; et al. Association between inherited germline mutations in cancer predisposition genes and risk of pancreatic cancer. JAMA 2018, 319, 2401-2409. [CrossRef]

71. Brand, R.; Borazanci, E.; Speare, V.; Dudley, B.; Karloski, E.; Peters, M.L.B.; Stobie, L.; Bahary, N.; Zeh, H.; Zureikat, A.; et al. Prospective study of germline genetic testing in incident cases of pancreatic adenocarcinoma. Cancer 2018, 124, 3520-3527. [CrossRef]

72. Wang, W.; Chen, S.; Brune, K.A.; Hruban, R.H.; Parmigiani, G.; Klein, A.P. PancPRO: Risk assessment for individuals with a family history of pancreatic cancer. J. Clin. Oncol. 2007, 25, 1417-1422. [CrossRef] 
73. Brand, R.E.; Lerch, M.M.; Rubinstein, W.S.; Neoptolemos, J.P.; Whitcomb, D.C.; Hruban, R.H.; Brentnall, T.A.; Lynch, H.T.; Canto, M.I. Advances in counselling and surveillance of patients at risk for pancreatic cancer. Gut 2007, 56, 1460-1469. [CrossRef]

74. Canto, M.I.; Harinck, F.; Hruban, R.H.; Offerhaus, G.J.; Poley, J.W.; Kamel, I.; Nio, Y.; Schulick, R.S.; Bassi, C.; Kluijt, I.; et al. International Cancer of the Pancreas Screening (CAPS) Consortium summit on the management of patients with increased risk for familial pancreatic cancer. Gut 2013, 62, 339-347. [CrossRef]

75. Canto, M.I. Strategies for screening for pancreatic adenocarcinoma in high-risk patients. Semin. Oncol. 2007, 34, 295-302. [CrossRef] [PubMed]

76. Vasen, H.; Ibrahim, I.; Ponce, C.G.; Slater, E.P.; Matthäi, E.; Carrato, A.; Earl, J.; Robbers, K.; van Mil, A.M.; Potjer, T.; et al. Benefit of surveillance for pancreatic cancer in high-risk individuals: Outcome of long-term prospective follow-up studies from three European expert centers. J. Clin. Oncol. 2016, 34, 2010-2019. [CrossRef] [PubMed]

77. Canto, M.I.; Almario, J.A.; Schulick, R.D.; Yeo, C.J.; Klein, A.; Blackford, A.; Shin, E.J.; Sanyal, A.; Yenokyan, G.; Lennon, A.M.; et al. Risk of neoplastic progression in individuals at high risk for pancreatic cancer undergoing long-term surveillance. Gastroenterology 2018, 155, 740-775. [CrossRef] [PubMed]

78. Lu, C.; Xu, C.F.; Wan, X.Y.; Zhu, H.T.; Yu, C.H.; Li, Y.M. Screening for pancreatic cancer in familial high-risk individuals: A systematic review. World J. Gastroenterol. 2015, 21, 8678-8686. [CrossRef] [PubMed]

79. Golan, T.; Kanji, Z.S.; Epelbaum, R.; Devaud, N.; Dagan, E.; Holter, S.; Aderka, D.; Paluch-Shimon, S.; Kaufman, B.; Gershoni-Baruch, R.; et al. Overall survival and clinical characteristics of pancreatic cancer in BRCA mutation carriers. Br. J. Cancer 2014, 111, 1132-1138. [CrossRef] [PubMed]

80. Sehdev, A.; Gbolahan, O.; Hancock, B.A.; Stanley, M.; Shahda, S.; Wan, J.; Wu, H.H.; Radovich, M.; O’Neil, B.H. Germline and somatic DNA damage repair gene mutations and overall survival in metastatic pancreatic adenocarcinoma patients treated with FOLFIRINOX. Clin. Cancer Res. 2018, 24, 6204-6211. [CrossRef] [PubMed]

81. NCCN Guidelines Version 2.2018 Pancreatic Adenocarcinoma. Available online: https://www.nccn.org/ professionals / physician_gls / default.aspx (accessed on 25 December 2018).

82. Takahashi, H.; Morizane, C.; Nomura, S.; Okano, N.; Tsuda, M.; Mizuno, N.; Satake, H.; Tsuji, K.; Shioji, K.; Ishii, H.; et al. Phase II clinical trial of gemcitabine plus oxaliplatin combination therapy (GEMOX) in patients with advanced pancreatic adenocarcinoma with a family history of pancreatic breast ovarian prostate cancer or personal history of breast ovarian prostate cancer. Ann. Oncol. 2018, 29 (Suppl. 8), viii205-viii270. [CrossRef]

83. Turk, A.A.; Wisinski, K.B. PARP inhibitors in breast cancer: Bringing synthetic lethality to the bedside. Cancer 2018, 124, 2498-2506. [CrossRef]

84. Farmer, H.; McCabe, N.; Lord, C.J.; Tutt, A.N.; Johnson, D.A.; Richardson, T.B.; Santarosa, M.; Dillon, K.J.; Hickson, I.; Knights, C.; et al. Targeting the DNA repair defect in BRCA mutant cells as a therapeutic strategy. Nature 2005, 434, 917-921. [CrossRef] [PubMed]

85. Bryant, H.E.; Schultz, N.; Thomas, H.D.; Parker, K.M.; Flower, D.; Lopez, E.; Kyle, S.; Meuth, M.; Curtin, N.J.; Helleday, T. Specific killing of BRCA2-deficient tumours with inhibitors of poly(ADP-ribose) polymerase. Nature 2005, 434, 913-917. [CrossRef] [PubMed]

86. Kaufman, B.; Shapira-Frommer, R.; Schmutzler, R.K.; Audeh, M.W.; Friedlander, M.; Balmaña, J.; Mitchell, G.; Fried, G.; Stemmer, S.M.; Hubert, A.; et al. Olaparib monotherapy in patients with advanced cancer and a germline BRCA1/2 mutation. J. Clin. Oncol. 2015, 33, 244-250. [CrossRef] [PubMed]

87. Shroff, R.T.; Hendifar, A.; McWilliams, R.R.; Geva, R.; Epelbaum, R.; Rolfe, L.; Goble, S.; Lin, K.K.; Biankin, A.V.; Giordano, H.; et al. Rucaparib monotherapy in patients with pancreatic cancer and a known deleterious BRCA mutation. JCO Precis. Oncol. 2018. [CrossRef] [PubMed]

88. Lowery, M.A.; Kelsen, D.P.; Capanu, M.; Smith, S.C.; Lee, J.W.; Stadler, Z.K.; Moore, M.J.; Kindler, H.L.; Golan, T.; Segal, A.; et al. Phase II trial of veliparib in patients with previously treated BRCA-mutated pancreas ductal adenocarcinoma. Eur. J. Cancer 2018, 89, 19-26. [CrossRef] [PubMed]

89. De Bono, J.; Ramanathan, R.K.; Mina, L.; Chugh, R.; Glaspy, J.; Rafii, S.; Kaye, S.; Sachdev, J.; Heymach, J.; Smith, D.C.; et al. Phase I, dose-escalation, two-parttrial of the PARP inhibitor talazoparib in patients with advanced germline BRCA1/2 mutations and selected sporadic cancers. Cancer Discov. 2017, 7, 620-629. [CrossRef] 
90. O'Reilly, E.M.; Lee, J.W.; Lowery, M.A.; Capanu, M.; Stadler, Z.K.; Moore, M.J.; Dhani, N.; Kindler, H.L.; Estrella, H.; Maynard, H.; et al. Phase 1 trial evaluating cisplatin, gemcitabine, and veliparib in 2 patient cohorts: Germline BRCA mutation carriers and wild-type BRCA pancreatic ductal adenocarcinoma. Cancer 2018, 124, 1374-1382. [CrossRef]

91. Kowalewski, A.; Szylberg, Ł.; Saganek, M.; Napiontek, W.; Antosik, P.; Grzanka, D. Emerging strategies in BRCA-positive pancreatic cancer. J. Cancer Res. Clin. Oncol. 2018, 144, 1503-1507. [CrossRef]

92. McCabe, N.; Turner, N.C.; Lord, C.J.; Kluzek, K.; Bialkowska, A.; Swift, S.; Giavara, S.; O'Connor, M.J.; Tutt, A.N.; Zdzienicka, M.Z.; et al. Deficiency in the repair of DNA damage by homologous recombination and sensitivity to poly (ADP-ribose) polymerase inhibition. Cancer Res. 2006, 66, 8109-8115. [CrossRef] [PubMed]

93. Lord, C.J.; Ashworth, A. BRCAness revisited. Nat. Rev. Cancer 2016, 16, 110-120. [CrossRef]

94. Torphy, R.J.; Zhu, Y.; Schulick, R.D. Immunotherapy for pancreatic cancer: Barriers and breakthroughs. Ann. Gastroenterol. Surg. 2018, 2, 274-281. [CrossRef] [PubMed]

95. Kunk, P.R.; Bauer, T.W.; Slingluff, C.L.; Rahma, O.E. From bench to bedside a comprehensive review of pancreatic cancer immunotherapy. J. Immunother. Cancer 2016, 4, 14. [CrossRef]

96. Brahmer, J.R.; Tykodi, S.S.; Chow, L.Q.; Hwu, W.J.; Topalian, S.L.; Hwu, P.; Drake, C.G.; Camacho, L.H.; Kauh, J.; Odunsi, K.; et al. Safety and activity of anti-PD-L1 antibody in patients with advanced cancer. $N$. Engl. J. Med. 2012, 366, 2455-2465. [CrossRef] [PubMed]

97. Le, D.T.; Uram, J.N.; Wang, H.; Bartlett, B.R.; Kemberling, H.; Eyring, A.D.; Skora, A.D.; Luber, B.S.; Azad, N.S.; Laheru, D.; et al. PD-1 Blockade in Tumors with Mismatch-Repair Deficiency. N. Engl. J. Med. 2015, 372, 2509-2520. [CrossRef] [PubMed]

98. Overman, M.J.; McDermott, R.; Leach, J.L.; Lonardi, S.; Lenz, H.J.; Morse, M.A.; Desai, J.; Hill, A.; Axelson, M.; Moss, R.A.; et al. Nivolumab in patients with metastatic DNA mismatch repair-deficient or microsatellite instability-high colorectal cancer (CheckMate 142): An open-label, multicentre, phase 2 study. Lancet Oncol. 2017, 18, 1182-1191. [CrossRef]

99. Le, D.T.; Durham, J.N.; Smith, K.N.; Wang, H.; Bartlett, B.R.; Aulakh, L.K.; Lu, S.; Kemberling, H.; Wilt, C.; Luber, B.S.; et al. Mismatch repair deficiency predicts response of solid tumors to PD-1 blockade. Science 2017, 357, 409-413. [CrossRef]

100. Prescribing Information of KEYTRUDA. Available online: https:/ / www.accessdata.fda.gov/drugsatfda docs/label/2017/125514s014lbl.pdf (accessed on 25 December 2018).

101. Humphris, J.L.; Patch, A.M.; Nones, K.; Bailey, P.J.; Johns, A.L.; McKay, S.; Chang, D.K.; Miller, D.K.; Pajic, M.; Kassahn, K.S.; et al. Hypermutation in pancreatic cancer. Gastroenterology 2017, 152, 68-74. [CrossRef]

102. Stockley, T.L.; Oza, A.M.; Berman, H.K.; Leighl, N.B.; Knox, J.J.; Shepherd, F.A.; Chen, E.X.; Krzyzanowska, M.K.; Dhani, N.; Joshua, A.M.; et al. Molecular profiling of advanced solid tumors and patient outcomes with genotype-matched clinical trials: The Princess Margaret IMPACT/COMPACT trial. Genome Med. 2016, 8, 109. [CrossRef]

103. Tanabe, Y.; Ichikawa, H.; Kohno, T.; Yoshida, H.; Kubo, T.; Kato, M.; Iwasa, S.; Ochiai, A.; Yamamoto, N.; Fujiwara, Y.; et al. Comprehensive screening of target molecules by next-generation sequencing in patients with malignant solid tumors: Guiding entry into phase I clinical trials. Mol. Cancer 2016, 15, 73. [CrossRef]

104. Matsubayashi, H.; Takaori, K.; Morizane, C.; Maguchi, H.; Mizuma, M.; Takahashi, H.; Wada, K.; Hosoi, H.; Yachida, S.; Suzuki, M.; et al. Familial pancreatic cancer: Concept, management and issues. World J. Gastroenterol. 2017, 23, 935-948. [CrossRef]

(C) 2019 by the authors. Licensee MDPI, Basel, Switzerland. This article is an open access article distributed under the terms and conditions of the Creative Commons Attribution (CC BY) license (http://creativecommons.org/licenses/by/4.0/). 